\title{
The Role of Notaries in the Registration of the Establishment of Commanditaire Vennootschap (CV) through the Business Entity Administration System
}

Henry Aspan*

Universitas Pembangunan Panca Budi, Medan, Indonesia

DOI: $10.36348 /$ sijlcj.2020.v03i12.007 $\quad$ | Received: 11.12 .2020 | Accepted: 23.12 .2020 | Published: 29.12 .2020

*Corresponding author: Henry Aspan

\section{Abstract}

Commanditaire Vennootschap (CV) is a non-legal entity such as a Limited Liability Company. However, the existence of a business entity does not reduce its rights, and obligations as a company recognized by the government, and business community in particular. CV is established based on the deed of the establishment made before a Notary and registered with the Minister through the Business Entity Administration System. With the provisions that the business activities of the CV must be following the 2017 Indonesian Standard Business Classification. The authority of the Notary is given by Law to make absolute evidentiary devices or tools, and therefore the authentic deed is in essence considered correct.

Keywords: Notary, Commanditaire Vennootschap, Business Entity, Indonesia.

Copyright ( $) 2020$ The Author(s): This is an open-access article distributed under the terms of the Creative Commons Attribution 4.0 International License (CC BY-NC 4.0) which permits unrestricted use, distribution, and reproduction in any medium for non-commercial use provided the original author and source are credited.

\section{INTRODUCTION}

A notary is a public official who carries out some of his/her government duties, especially in the private law field. The Notary Position in Indonesia is regulated by Law Number 30 of 2004 concerning Notary Position, which has then been amended by the issuance of Law Number 2 of 2014 concerning Amendments to Law Number 30 of 2004 concerning Notary Position [1].

According to article 1 number 1 UUJN, a notary is defined as a public official who has the authority to do authentic deeds and has other powers as referred to in UUJN or based on other laws. The notary definition given by the UUJN implies that a notary has the duty as a public official and has the authority to make authentic deeds and other powers regulated by UUJN and other laws [2].

As a public official, a Notary is appointed by the Minister of Law and Human Rights of the Republic of Indonesia, based on article 2 UUJN. With the appointment of a Notary, the Notary can carry out his/her duties freely, without being influenced by the executive body and other bodies and can act neutrally and independently [3].

One of the Ministries that issued revolutionary regulations was the Ministry of Law and Human Rights.
This time, the targets of the curbing are business entities in the form of Commanditaire Vennootschap (CV), firm alliance, to a civil partnership [4].

The Ministry of Law and Human Rights of the Republic of Indonesia, referring to Government Regulation Number 24 of 2018, concerning Electronically Integrated Business Licensing Services issued a Regulation of the Minister of Law and Human Rights of the Republic of Indonesia Number 17 of 2018 concerning registration of limited partnership, firm alliance and civil partnership, from now on referred to as Regulation of the Minister of Law and Human Rights of the Republic of Indonesia No. 17/2018 [5].

This rule revolutionizes the rules that so far require that the deed of establishment of $\mathrm{CV}$, Firm and Civil Association, which is made before a Notary, must be registered at the local District Court following article 23 of the KUHD. The report states that "the firms of the company are obliged to register the deed in the register provided for this at the registrar's office of raad van justitie (district court) in the jurisdiction of the domicile of company [6]."

Based on Regulation of the Minister of Law and Human Rights of the Republic of Indonesia No. 17/2018, registration of CVs, Firms and Civil Associations is now carried out entirely online, namely 
through the Business Entity Administration System. From the preliminary description above, in general, the research questions in this manuscript are as follows: RQ1; What are the requirements for establishing a CV? RQ2; What is the role of the Notary in CV registration through the Business Entity Administration System? RQ3; What is the procedure for registering CV establishment through the Business Entity Administration System?

\section{LITERATURE REVIEW}

\section{Requirements for Establishing a Commanditaire Vennootschap (CV)}

Limited partnership or better known as Commanditaire Vennootschap (CV) is a non-legal entity such as a Limited Liability Company. Nevertheless, the existence of this business entity does not reduce its rights and obligations as a company recognized by the government and the business community in particular. This case can be seen from the number of entrepreneurs, especially Small and Medium Entrepreneurs. They use CV as a foundation to be able to carry out business activities in Indonesia.

Based on Regulation of the Minister of Law and Human Rights of the Republic of Indonesia No. 17/2018 Article 1 paragraph (1), CV is an association established by one or more limited partners with one or more complementary partners, to run a business continuously. Meanwhile, according to Article 19 of the KUHD, CV is a company formed by lending money which is established between a person or between several partners who are jointly and severally responsible for the whole, and one or more people as money lenders.

$\mathrm{CV}$ is established based on the deed of the establishment made before a Notary and registered with the Minister through the Business Entity Administration System. With the provision that CV's business activities must be following the 2017 Indonesian Standard Business Field Classification to comply with Government Regulation Number 24 of 2018 concerning Electronic License Management.

Article 19 paragraph (1) of the Indonesian Commercial Code, explains that $\mathrm{CV}$ is an alliance by releasing money which is called a limited partnership, established between one person or several allies who bear responsibility for all on one party, and one person. or more as a money lender to another party. Whereas in Article 19, paragraph 2 it reads "Thus there can be an alliance that at one time is a firm partnership with firm partners in it and is a limited partnership with moneylenders". In several other references, the provision of capital loans or so-called inbreng can be in the form other than money, for example, objects or others.

The limited partnership or $\mathrm{CV}$ is regulated in articles 19-21 of the Indonesian Commercial Code. CV is a non-legal entity that associates capital from two or more people, which is divided into two types of allies, namely complementary partners and limited partners.

Complementary allies called active allies, are in charge of the company's operational activities and are fully entitled to enter into work agreements with third parties. Meanwhile, limited partners are called passive allies, who only have to hand over income as capital for the partnership. This ally is not responsible for the company's operations.

Complementary allies are parties who are fully responsible for the existence of $\mathrm{CV}$, as written in Article 19 of the Indonesian Commercial Code (KUHD). Meanwhile, the limited partnership itself has to deliver goods, services, or money as CV capital but is not responsible for the sustainability of the $\mathrm{CV}$ itself.

With 2 (two) kinds of allies, there is also a difference in responsibilities between the two. A complimentary partner will do: (1) give inbreng in the form of money, goods, energy or thoughts; (2) name the company; (3) make arrangements; and (4) fully responsible for personal assets.

Meanwhile, a limited partnership basically will: (1) give inbreng in the form of money or goods; (2) may not name the company; (3) may not make arrangements; and (4) is liable for a limited amount of inbreng that the limited partnership allies have deposited.

In the Commanditaire Vennootschap (CV), there is a clear difference in responsibilities between limited-responsible limited-allies and complementary allies who are responsible for personal property. With this form of accountability in the Commanditaire Vennootschap (CV), it is often said that this business entity is an intermediate business entity towards the form of a Limited Liability Company.

In establishing a company, the business actor must make a deed of establishment beforehand to a notary public. Based on Article 1 number (7) UUJN that, Notary Deed is an authentic deed made by or before a Notary according to the forms and procedures stipulated in this Law.

An authentic deed becomes evidence of every validity of an agreement or legal action contained therein. Making the legal product of the notary public must follow the manufacturing procedure as stipulated in the laws and regulations. Which means that what is stated in the deed must be considered authentic, until there is a party, namely usually the opposing party must be able to prove that what is said in the deed is incorrect. One of the conditions for the validity of agreement regulated in Article 1320 of the Civil Code is the ability of the parties to agree. 
Therefore, to make a deed of $\mathrm{CV}$ establishment, which is made before a notary public, several requirements must be fulfilled, namely as follows: (a) The name to be used for the name of the CV; (b) Photocopy of E-KTP must be attached by each person involved in the formation of $\mathrm{CV}$ either as an active or passive partner; (c) Place of domicile of CV along with complete address; (d) Complete aims and objectives with the specific establishment of the CV; (e) Name of the ally in power (as the person who signs the agreement on behalf of the partnership); (f) Other important clauses, relating to Third Parties against founding partners.

After the above conditions have been met, the Notary will start with the first step, namely checking the name of CV. And if the name of CV is approved, and can be used, the Notary then makes a deed of CV to be signed by the company before the Notary. Then the Notary makes a copy of the deed of establishment of the $\mathrm{CV}$ and registers the deed at the Ministry of Law and Human Rights to get a Registered Certificate that validates the deed.

\section{The Role of Notaries in CV Registration through the Business Entity Administration System}

Notaries in performing their duties are based on UUJN. In the provisions of the Notary Position Regulation and UUJN in essence, it states that the main task of a notary is to do authentic deeds. In Article 1870 of the Civil Code, it is noted that an original deed gives an absolute agreement to the parties who make it. Thus, the importance of the position of a Notary is in the authority of the Notary which is given by Law to make absolute evidentiary devices or tools and therefore the authentic deed is in essence considered correct. Consequently, it is imperative, especially for those who need it in personal or business matters.

Notary deeds play an essential role in creating legal certainty because of their authenticity and can be used as a vital and full proof tool in case of problems related to the deed. Nowadays, the need for authentic deeds as proof is increasing along with increasing business relations in various business fields, from local to an international scale.

For anyone who wants to set up a company like a CV, a Deed is the first step in the legality process. Any Business Entity needs a Deed to certify the business entity they wish to establish. Company deeds and registration are basic requirements needed to continue the process of working on the next document.

The role of the Notary in online CV registration is starting from entering $\mathrm{CV}$ data to checking the CV name according to the wishes of the Applicant. If the $\mathrm{CV}$ name is approved, then the $\mathrm{CV}$ establishment deed is signed. Likewise, when entering data at the time of $\mathrm{CV}$ registration, caution is required.
Data errors during the process of entering data into the system are unwanted by anyone, but sometimes they still happen. This situation indeed cannot be separated from the role of the Notary. If there is an error in data entry, the role of the Notary is to correct the data before it is inputted or uploaded. The Notary checks the wrong part and matches the data brought by the Applicant because if there is an error on the part of the Notary Public, the Notary must be responsible by doing a new deed at the expense of the Notary, however, if the Applicant makes an error, the Notary will tell what is appropriate, what steps will be taken in connection with the error. This case is where the Notary's role is vital in carefully entering data into the system.

If there is an error in entering data in the registration of $\mathrm{CV}$ establishment, then this will have an impact when submitting Business Identification Number which is an identification number for business actors, through the Online Single Submission system. Notaris dalam melaksanakan tugas dan jabatan serta kewenangan Notaris akan tetap berada pada tataran hukum, sehingga akan ada selalu masalah dan solusinya. Masalah timbul karena: (a) Ketidak hatianhatian secara normatif; (b) Dimasalahkan oleh pihak lain. As long as the rules are still made by humans, there is always a solution to the problem in question.

\section{Registration Procedure for CV Establishment through the Business Entity Administration System}

Since the issuance of Permenkumham RI No. $17 / 2018$, the application for registration of the establishment of a CV must be made first by submitting the name of the CV. This case is as standard with the establishment of a Limited Liability Company or Foundation legal entity. The Applicant carries out the application process for the use of names to the Minister through the Business Entity Administration System (Article 5). The Applicant is the joint founder or allies who will register $\mathrm{CVs}$, firms, and civil associations that authorize Notaries to submit applications through the Business Entity Administration System (article 1).

The name of the CV submitted must meet the following requirements: (1) It is written in Latin letters; (2) Has not been used legally by another CV in the Business Entity Administration System; (3) Does not conflict with public order and/or morality; (4) Does not match or is not similar to the names of state institutions, government agencies, or international institutions unless they receive permission from the relevant institutions; and (5) Does not consist of numbers or a series of numbers, letters, or a series of letters that do not form a word.

Submission of names is made electronically by filling in the Name Submission Format which at least contains: (1) Payment number for approval of use of $\mathrm{CV}$ name from the bank of perception; and (2) the name of the $\mathrm{CV}$ ordered. Applications for submitting $\mathrm{CV}$ 
names are subject to fees under the provisions of laws and regulations in the field of Non-Tax State Revenue based on Government Regulation Number 28 of 2019 concerning Types and Rates for Types of Non-Tax State Revenue Applicable to the Ministry of Law and Human Rights or abbreviated PP No. 28/2019. Payment of fees is made through a perception bank under the provisions of laws and regulations. After submitting a name application, the Applicant must wait for approval from the Minister.

According to Article 7 of the Regulation of the Minister of Law and Human Rights of the Republic of Indonesia No. 17/2018, approval for the use of the names CV, Firm, and Civil Unions are given by the Minister electronically. The agreement at least contains (1) Order number name of $\mathrm{CV}$, firm, and civil association; (2) Usable terms of CV, Firm, and civil partnership; (3) the date of order; (4) Expiration date; and (5) Payment code.

Approval only for 1 (one) name CV. If the name does not meet the requirements for submitting and using the name $\mathrm{CV}$, then the Minister can reject the name $\mathrm{CV}$. The use of the name $\mathrm{CV}$ which has been approved by the Minister, is valid for a maximum period of 60 (sixty) days. So, the name that has been approved must be followed up immediately by making a deed of $\mathrm{CV}$ and proceed to the registration process through SABU. Furthermore, the Applicant must submit an application for registration of $\mathrm{CV}$ establishment through the Business Entity Administration System not later than 60 (sixty) days from the date of the deed of establishment of CV. Applications are made by filling in the Registration Format. If the registration for the establishment of a CV exceeds the period, the application for registration for the establishment of a CV cannot be submitted to the Minister.

Registration of CV establishment is subject to fees following PP No. 28/2019. Payment of registration fees is made through the perception bank under the provisions of laws and regulations. Filling in the Registration Format is uploaded electronically and must also be accompanied by supporting documents in the form of (1) Electronic statement from the Applicant stating that the documents for $\mathrm{CV}$ registration are complete; and (2) a report from the corporation regarding the accuracy of the information on the beneficial owner of $\mathrm{CV}$.

The Petitioner must also upload the deed of establishment of CV. Documents for CV registration are kept by the Notary, which include: (1) Minuta deed of the $\mathrm{CV}$ which at least contains: Identity of the founder consisting of the name of the founder, domicile, and occupation; Business activities; The rights and obligations of the founders; and the term of CV. (2)
Photocopy of certificate regarding the complete address of CV [7].

The Applicant is obliged to fill in an electronic statement stating that the Registration Format and information regarding the supporting documents are following the provisions of laws and regulations. The Applicant is fully responsible for the Registration Format and information, unlike the Limited Liability Company, which after being registered gets the final product in the form of a Ministerial Decree or Notification of Acceptance of Amendments to Articles of Association or company data [8].

Every online $\mathrm{CV}$ registration results in a Registered Certificate. Unlike the Limited Liability Company, this Registered Certificate (SKT) is not proof of the validation or confirmation of the $\mathrm{CV}$ as a legal entity. The Minister issues a CV Registered Certificate electronically. In this case, the Notary can immediately print his own CV's Registered Certificate using whitecoloured paper with the size of F4 / folio with a weight of 80 (eighty) grams. As with the provisions in the printing of a Limited Liability Company Approval Decree, the Registered Certificate must be signed and affixed with a position stamp by the Notary and contain a phrase stating "This Registered Certificate is printed from the Business Entity Administration System [9]."

Application for registration of $\mathrm{CV}$ establishment at BEAS must be submitted no later than 60 (sixty) days from the date the deed of establishment of $\mathrm{CV}$ is signed. If the registration of the $\mathrm{CV}$ establishment exceeds 60 (sixty) days, the registration of the establishment cannot be submitted to the Minister.

\section{CONCLUSION \& SUGGESTIONS}

Based on the description of the discussion above, the following conclusions can be drawn: (1) The legal basis for the establishment of Commanditaire Vennootschap $(\mathrm{CV})$ is based on the Indonesian Commercial Code and the Civil Code. CV was established by 2 (two) or more people, based on the deed of the establishment made before a Notary and registered with the Minister of Law and Human Rights through the Business Entity Administration System. (2) Based on article 23 KUHD, registration for the establishment of CV is carried out at the Registrar's Office of the District Court. However, currently, the government has issued Permenkumham RI No. 17/2018 where the registration is similar to the registration of a legal entity, which is carried out to the Minister through the Business Entity Administration System (BEAS). (3) The Notary plays a role in making the deed of establishment of the $\mathrm{CV}$ and registering the $\mathrm{CV}$ at BEAS, by registering it through predetermined stages, by filling in the format in the Business Entity Administration System. 
Regulation of the Minister of Law and Human Rights of the Republic of Indonesia No. 17/2018 is expected to be more disseminated to the public, mostly micro and small entrepreneurs who lack information. And provide convenience in its implementation and provide a different platform that can provide information about questions that arise during the execution of these regulations.

\section{REFERENCE}

1. Adjie, H. (2011). Aspek Pertanggungjawaban Notaris dalam Pembuatan Akta. Mandar Maju, Bandung.

2. Suryani, N., Mantili, R., \& Afriana, A. (2015). Hukum Perusahaan, Universitas Terbuka, Tangerang Selatan.

3. Basuki, Z. D., Hikmah, M., \& Penasthika, P. P. (2016). Hukum Dagang dan Kepailitan, Universitas Terbuka, Tangerang Selatan.
4. Subekti, R., \& Tjitrosudibio, R. (1999). Kitab Undang-Undang Hukum Dagang dan UndangUndang Kepailitan, PT. Pradnya Paramita, Jakarta. https://irmadevita.com/2018/sabu-sistempendaftaran-online-untuk-cv-firma-danpersekutuan-perdata, 6 September, 2020.

5. Kitab Undang-Undang Hukum Dagang.

6. Undang-Undang Nomor 30 Tahun tentang Jabatan Notaris.

7. Undang-Undang Nomor 2 Tahun 2014 tentang Perubahan atas Undang-Undang Nomor 30 Tahun 2004 tentang Jabatan Notaris.

8. Peraturan Pemerintah Nomor 24 Tahun 2018 tentang Pelayanan Perizinan Berusaha Terintegrasi Secara Elektronik.

9. Peraturan Menteri Hukum dan Hak Asasi Manusia Republik Indonesia Nomor 17 Tahun 2018 tentang Pendaftaran Persekutuan Komanditer, Persekutuan Firma, dan Persekutuan Perdata. 